\title{
Challenges in validating candidate therapeutic targets in cancer
}

\begin{abstract}
More than 30 published articles have suggested that a protein kinase called MELK is an attractive therapeutic target in human cancer, but three recent reports describe compelling evidence that it is not. These reports highlight the caveats associated with some of the research tools that are commonly used to validate candidate therapeutic targets in cancer research.
\end{abstract}

\section{JEFFREY SETTLEMAN, CHARLES L SAWYERS AND TONY HUNTER}

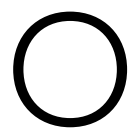

ver the past two decades or so, a significant fraction of cancer-related research has been focused on the discovery and validation of candidate therapeutic targets. These efforts have unquestionably yielded findings that have provided a critical foundation for the development of many successful oncology drugs - most notably, a variety of inhibitors of oncogenic kinases and several relatively new immunotherapeutic agents that have already provided clinical benefit to many patients. At the same time, despite the best efforts of the community, a large number of published reports that claim to have discovered a new target fail to achieve a sufficient level of follow-up validation, either pre-clinically or clinically.

Here, we provide some perspective on this important challenge to the field, highlighting as an example the maternal embryonic leucine zipper kinase (MELK). This protein kinase has been implicated in cancer in dozens of publications spanning more than a decade, but its role in cancer has now been called into question by three recent articles in eLife (Lin et alo, 2017; Huang et al., 2017; Giuliano et al., 2018). We focus on three topics in particular: the use of cancer cell lines as models for target validation and therapeutic efficacy; the use of RNA interference for target validation; and the use of small-molecule pharmacologic inhibitors.

\section{Issues related to the use of cancer cell lines}

Among the key challenges faced by cancer researchers aiming to validate candidate therapeutic targets are the limitations of the model systems and reagents available to them. Most investigators rely heavily on human cancerderived cell lines and associated tumor xenografts in mice to examine the role of candidate genes and the efficacy of candidate therapeutics. Such models have several attractive attributes. For example, there are hundreds of such cell lines derived from a variety of tissue types that are commercially available, and their diversity has the potential to capture the increasingly recognized heterogeneity among tumors associated with the real-world patient population. In addition, most of these cell lines have now been genomically annotated, and information regarding mutations, gene expression, and other 'omic' features is now readily accessible through various public databases. And, importantly, these models have proved to faithfully capture at least some elements of target dependency and pharmacologic efficacy that have successfully translated to the clinic (Sharma et al., 2010).

While cell line models have been an invaluable tool for cancer researchers, they are not without problems. Cell line identity issues, which have led to many erroneous published claims, have attracted increasing attention, but can now 
be effectively managed through STR-based 'fingerprinting' (Freedman et al., 2015). As a result, this is expected to become a less frequent problem with time. However, the 'same' cell line tested in two different laboratories can yield different results - potentially reflecting seemingly minor, but functionally consequential differences in culture conditions (such as media type, serum source, plating density, 2D vs 3D culture, cell line source, and passage history). There is also the epigenetic drift that can arise during long-term passage in culture and can lead to a change in the phenotypic properties of the culture that significantly impacts specific gene dependencies as well as response to therapeutic treatments - even among isogenicallymatched lines.

Furthermore, while most investigators now appreciate the importance of testing therapeutic hypotheses in multiple cancer models (owing to disease heterogeneity), findings that emerge from a 'handful' of tested cell lines sometimes fail to extend to a larger panel of models upon broader analysis, especially in cases where a biomarker-response correlation is relatively weak. Platforms that enable such testing on a very large scale (hundreds of cancer cell lines) have emerged only recently, and while such platforms are not yet readily accessible to most researchers, they have the potential to provide important additional contextual information to support therapeutic claims, thereby providing insights to guide prioritization of the most attractive candidate targets emerging from the literature (Garnett et al., 2012).

\section{Issues related to the use of RNA interference}

We now discuss the some of the reagents that are used to model gene dependency and pharmacologic responsiveness. RNA interference, in the form of siRNAs and shRNAs, has been widely used to test the functional requirement for genes of interest in cancer cell models. While this is unquestionably a powerful methodology, it is also widely recognized that it is fraught with the potential to produce misleading results due to off-target effects. Many investigators try to mitigate this problem by using multiple RNAi reagents directed against the same target, or to use 'rescue constructs' to verify the on-target nature of any observed effects. However, the typical assay endpoints that are relevant to cancer cells - such as the inhibition of cell proliferation or the induction of cell death - are especially vulnerable to off-target effects that might impact a large number of functionally important genes. Consequently, the results of such studies can be misleading, even when controls are included.

More recently, CRISPR-based methods to evaluate gene dependency in cultured cells have become increasingly used. This technology, which appears to be less prone to off-target effects, is gradually replacing RNAi methodology for many investigators and could, therefore, eventually reduce the number of spurious findings related to target validation efforts.

\section{Issues related to the use of small- molecule inhibitors}

A second class of reagent - pharmacologic tool compounds, especially 'small-molecule' inhibitors - is widely used for target validation in cancer cells and xenografted tumors. Such compounds, which are widely reported in the cancer literature, and are readily available from a large number of commercial vendors, can be even more problematic than RNAi reagents.

First, the identity and purity of these compounds is often uncertain and highly variable. Thus, a recent report that included analysis of more than 8,500 purchased small-molecule pharmacologic agents revealed that $29 \%$ of these compounds did not pass quality control testing (Corsello et al., 2017). Unfortunately, most investigators do not have the means to easily test the quality of these purchased materials and, therefore, they proceed under the assumption that they have received reagents of adequate quality for experimentation.

Second, it is now widely acknowledged that many small-molecule inhibitors can affect multiple cellular proteins, in addition to the protein of interest. In many cases, the identity of the offtarget proteins may not even be known. Unfortunately, it is generally difficult to perform an appropriate 'rescue' study to verify the on-target nature of any observed effects of these compounds, consequently leading to a large number of published reports that erroneously attribute the effects of such inhibitors to the wrong target.

The extent to which such reports have misled the cancer research community is unknown, but is likely to be substantial. Notably, there are now many examples of published studies that compellingly demonstrate the off-target effects of putative selective inhibitors. However, despite such reports, investigators continue to publish 
The extent to which such reports have misled the cancer research community is unknown, but is likely to be substantial.

findings based on the presumption of a selective activity of those very same inhibitors. For example, in 2014 Heinemann et al. reported compelling evidence that a histone demethylase inhibitor called GSK-J1/J4 acted on a number of histone demethylases (Heinemann et alo, 2014) and was not, therefore, a selective inhibitor, as had been previously reported (Kruidenier et al., 2012; see also Kruidenier et alo, 2014). However, despite this exchange being published in Nature, more than a dozen subsequent publications have described studies that yielded conclusions based on the use of GSK-J1/J4 to selectively target the KDM6/JMJD3 demethylases. Of course, it is also widely recognized that there are very few truly mono-selective pharmacologic small molecules; and yet, many of these have been useful both as research tools and as drugs. But it is important that investigators take appropriate measures to increase the likelihood that any observed effects of these agents reflect their interaction with the intended target or targets.

\section{MELK as a case study}

Having described a few of the factors that challenge our ability to validate targets, let's consider the case of MELK. This leucine zippercontaining serine/threonine kinase was first reported 20 years ago as a new member of the AMP kinase family whose expression is increased in pre-implantation mouse embryos, implicating MELK in early development (Heyer et alo, 1997). In 2005, MELK was first implicated in cancer in a study that reported elevated levels of MELK RNA expression in many human tumors and in a mouse colorectal cancer model, and demonstrated that MELK-targeted RNA-interference inhibited proliferation in cultured human cancer cell lines and also in a xenograft tumor model (Gray et al., 2005). Since that initial article, there have been another 32 articles that specifically implicate MELK as a therapeutic target in human cancer (see column 1 in Table 1), including an article by Wang et al. that was published in eLife in 2014 (Wang et al., 2014).

Of those 33 MELK-cancer publications, 20 articles describe studies indicating that MELK expression is up-regulated (mostly based on RNA levels) in various human cancers, including ovarian, breast, NSCLC, SCLC, AML, prostate, pancreas, gastric, renal, astrocytoma, glioma, medulloblastoma, colorectal, liver, and rectal cancers (see column 2 in Table 1). Fifteen of the published MELK expression studies also report an association between increased MELK expression and poor clinical prognosis (see column 3 in Table 1). Significantly, 23 of the published MELK studies report efficacy of MELK-targeted RNAi in cancer cell lines and/or xenograft tumor models, thereby directly implicating MELK function in cancer cell proliferation or tumorigenic potential (see column 4 in Table 1). Consistent with those findings, 19 published studies describe efficacy with small-molecule inhibitors of the MELK kinase in cancer cell lines and/or tumor xenografts (see column 5 in Table 1). Notably, 15 of those studies made use of the MELK inhibitor OTS167 (also known as OTSSP167) that is currently being evaluated in human clinical trials, presumably prompted by many of these published pre-clinical findings (see column 6 in Table 1). In aggregate, these published studies would seem to make a compelling case for a likely role for MELK in a variety of human cancers.

However, in March 2017, in an article published in eLife, researchers at the Cold Spring Harbor Laboratory (CSHL) and Stony Brook University reported that they had used CRISPR/ Cas9 technology to delete MELK in 13 different human cancer cell lines of various tissue origins, and that they had observed in no significant effects on proliferation (Lin et al., 2017). Notably, this analysis included several triple-negative breast cancer cell lines that, according to the 2014 eLife article by Wang et al., were MELKdependent (based on the observed consequences of RNAi-induced MELK depletion). Lin et al. also noted that in several published wholegenome, unbiased RNAi studies to identify genes required by cancer cells, MELK dependency was never observed. Furthermore, they observed that cancer cells depleted of MELK by CRISPR editing were found to retain sensitivity to the MELK kinase inhibitor OTS167. This led Lin et al. to conclude that the observed cytotoxicity following OTS167 treatment reflected offtarget, MELK-independent mechanisms, thus implying that the ongoing clinical development 


\section{The definitive validation of most of the well-established therapeutic targets resulted from the collective efforts of many independent groups over many years.}

of OTS167 as a MELK-targeted therapeutic may be misguided. Notably, three other relatively recent publications have similarly concluded that OTS167 is likely to exhibit MELK-independent cytotoxic activity (Huang et al., 2017; Simon et al., 2017; Ji et al., 2016).

A number of the authors on the first of these articles (Huang et al., 2017) were also authors on the 2014 elife article that implicated MELK as a therapeutic target in human cancer (Wang et al., 2014). However, the title of Huang et al. ("MELK is not necessary for the proliferation of basal-like breast cancer cells") confirmed the doubts that Lin et al. had raised about MELK as a target. Like Lin et al., the analysis by Huang et al. included CRISPR-mediated deletion of MELK in cancer cells, as well as the discovery of a novel potent and more MELK-selective inhibitor that failed to significantly affect the growth of putatively MELK-dependent cells. Huang et al. also employed a targeted protein degradation strategy to further support the conclusion that MELK is not a dependency gene in basal breast cancer. In addition, they analyzed various MELK-targeted shRNAs, including several that had been used in previous reports. This led to the conclusion that the differences in the findings reported by Wang et al. in 2014 and those reported by Huang et al. in 2017 were probably due to off-target effects, further highlighting the challenges involved in interpreting the results of RNAi studies in cancer cells.

Then, in early 2018, the CSHL group published a second article that refuted some of the other findings reported by Wang et al. in 2014 elife article, and seemingly providing the final 'nail in the coffin' for MELK as a target for cancer drugs (Giuliano et al., 2018). In particular, they reported that overexpression of MELK failed to transform immortalized cells, as had been previously claimed. They also generated several additional MELK-deficient cancer cells using CRISPR technology and failed to observe any effects on growth in culture or in xenograft tumor models. Furthermore, Giuliano et al. used a highly selective MELK inhibitor to show that acute MELK inhibition did not affect the proliferation or anchorage-independent growth of several tested cancer cell lines previously reported to be MELK-dependent.

So, what does this all mean for MELK as a therapeutic target? The three recent elife articles certainly call into question many of the previous reports regarding MELK dependency in cancer cells. The numerous published RNA expression studies, which are less likely to be affected by technical artifacts, are probably valid overall. However, those findings might simply reflect the fact that MELK is a cell cycle-regulated gene (Badouel et al., 2010) that may appear to be upregulated in relatively rapidly growing cell populations, but which is not necessarily a 'driver' of tumorigenesis. It also remains possible that a role for MELK in cancer is highly context-dependent or that cancer cells with some degree of MELK dependency are able to adaptively 'rewire' to accommodate MELK disruption. While these are formal possibilities, the findings reported in the three recent elife articles are likely to substantially diminish the enthusiasm for MELK as a therapeutic target.

These observations should serve as a stark reminder to the research community of the issues that arise when RNAi or pharmacologic tool compounds (in particular, small-molecule inhibitors) are used in studies that seek to validate candidate targets - even when numerous independent studies all reach similar conclusions. Moreover, the fact that cancer patients are currently being treated with OTS167 based on the published findings certainly highlights the importance of robust pre-clinical validation.

\section{Addressing the problem of target validation}

How should journals deal with such a scenario? In recent years, the research community has become increasingly aware of the challenge of reproducibility in biomedical research. Notably, elife is beginning to report findings from the Reproducibility Project: Cancer Biology, which is an ambitious effort to evaluate the scope of this problem in preclinical cancer research and to identify the factors that influence reproducibility more generally (Errington et al., 2014). And early results have already highlighted the challenges in robustly reproducing published findings. 
Table 1. Articles suggesting a link between MELK and human cancers.

Articles reporting Articles reporting an

that MELK

expression is up- increased MELK

regulated in various expression and poor human cancers clinical prognosis
Articles reporting efficacy of MELKtargeted RNAi in cancer cell lines and/or xenograft tumor models
Articles reporting efficacy with small-molecule use of the MELK inhibitors of MELK in cancer inhibitor OTS167 cell lines and/or xenograft (also known as tumor models OTSSP167) \begin{tabular}{ll}
\hline Gray et al. (2005) & $\times$ \\
\hline Lin et al. (2007) & $\times$ \\
\hline Marie et al. \\
$(2008)$
\end{tabular}

Nakano et al. $\quad x$ (2008)

Nakano et al. $\quad x$

(2009)

Pickard et al. x

(2009)

Hebbard et al.

(2010)

Choi and $\mathrm{Ku}$

(2011)

Chung et al.

(2012)

Gu et al. (2013) x

Kuner et al.

(2013)

Minata et al.

(2014)

Wang et al. $\mathrm{x}$

$x$

(2014)

Du et al. (2014) x $x \quad x$

Alachkar et al. $x \quad x \quad x$

(2014)

Beke et al. (2015)

$x$

Li et al. (2016)

Inoue et al. (2016) $x$

$x$

$\mathrm{X}$

$x$

Chung et al.

(2016)

Kato et al. (2016)

$x$

Touré et al., 2016

Wang et al.

(2016)

Stefka et al.

(2016)

Xia et al. (2016) x

Speers et al.,

2016

Hiwatashi et al., $\mathrm{x}$

2016

Kohler et al. x

(2017)

Simon et al.

(2017)

Edupuganti et al.

(2017)

Liu et al., $2017 \quad x$

Table 1 continued on next page

$x$

$\mathrm{x}$

$\mathrm{x}$

$x$

$\mathrm{x}$

$x$

$x$ 
Table 1 continued

\begin{tabular}{|c|c|c|c|c|c|}
\hline & $\begin{array}{l}\text { Articles reporting } \\
\text { that MELK } \\
\text { expression is up- } \\
\text { regulated in various } \\
\text { human cancers }\end{array}$ & $\begin{array}{l}\text { Articles reporting an } \\
\text { association between } \\
\text { increased MELK } \\
\text { expression and poor } \\
\text { clinical prognosis }\end{array}$ & $\begin{array}{l}\text { Articles reporting } \\
\text { efficacy of MELK- } \\
\text { targeted RNAi in cancer } \\
\text { cell lines and/or } \\
\text { xenograft tumor models }\end{array}$ & $\begin{array}{l}\text { Articles reporting efficacy } \\
\text { with small-molecule } \\
\text { inhibitors of MELK in cancer } \\
\text { cell lines and/or xenograft } \\
\text { tumor models }\end{array}$ & $\begin{array}{l}\text { Articles that made } \\
\text { use of the MELK } \\
\text { inhibitor OTS167 } \\
\text { (also known as } \\
\text { OTSSP167) }\end{array}$ \\
\hline $\begin{array}{l}\text { Matsuda et al. } \\
\text { (2017) }\end{array}$ & & & $x$ & & \\
\hline $\begin{array}{l}\text { Bolomsky et al., } \\
2017\end{array}$ & $x$ & $x$ & & $x$ & $x$ \\
\hline $\begin{array}{l}\text { Janostiak et al., } \\
2017\end{array}$ & $x$ & $x$ & $x$ & $x$ & $x$ \\
\hline
\end{tabular}

The 33 articles listed in column 1 of this table suggest that MELK has a role in a variety of human cancers, which makes in a candidate therapeutic target for cancer drugs. Columns 2-5 indicate which articles reported certain kinds of evidence to make the link between MELK and cancer, column 6 indicates the studies that used a MELK inhibitor called OTS167 (which is currently undergoing clinical trials). However, three recent papers (Lin et al., 2017; Huang et al., 2017; Giuliano et al., 2018) suggest that MELK should not be considered as a candidate therapeutic target.

Within the cancer research community, most investigators readily acknowledge that the validation of candidate targets is very challenging and is subject to a large number of variables that are difficult to adequately account for, even within a well-controlled experimental design (as described earlier). Moreover, these same investigators recognize that the definitive validation of most of the well-established therapeutic targets resulted from the collective efforts of many independent groups over many years, typically involving hundreds if not thousands of reported findings that were ultimately required to solidify the case.

Indeed, scientific discovery, in most cases, has historically been a self-correcting quest. Along the way, peer reviewers and journal editors do their best to ensure that published conclusions are supported by well-executed, scientifically-sound experimentation. And yet, we have a big problem. It is worth noting that, in our view, the authors of the early MELK validation articles listed in Table 1 were generally well intentioned, even if it appears, with the benefit of hindsight, that a number of the conclusions in these papers were mistaken. Whereas some might call for the retraction of all such articles a logistically complicated undertaking to be sure - we favor approaches that promote the selfcorrection of target validation claims over time (possibly including the publication of formal corrections to some especially problematic articles) and reduce the frequency of flawed claims in new reports.

So how can we do better going forward? Considering that RNAi and pharmacologic tool compound reagents may be an especially significant source of erroneous findings, there could be substantial value in standardizing criteria for the acceptable use of these reagents prior to publication. For example, the development of publicly accessible databases that track the reliability and specificity of such reagents could be very useful. Along these lines, a consortium of investigators has recently described a community-driven wiki resource (http://www.chemicalprobes.org/) to help researches make the best use of available chemical probes (Arrowsmith et al., 2015). A similar resource for RNAi reagents is likely to have tremendous value for the community. Investigators would obviously benefit from such a resource, as would journal editors and reviewers because they could quickly check the validity of the critical reagents described in manuscripts as part of the peer review process.

As for previously published articles that report conclusions based on potentially problematic reagents - which would seem to include a significant number of the articles on MELK - it could be useful for journals to 'tag' those articles that have relied on reagents whose specificity has subsequently been called into question This would be useful information for any researchers considering the extension or replication of findings reported in these articles. It would undoubtedly require an organized effort from the research and publishing communities, and significant time, to widely implement such approaches - and hopefully, this is where we are heading. In the meantime, it remains incumbent on scientists, peer reviewers and journal editors to apply adequately rigorous standards to ensure that published claims have a very high likelihood of 
standing the test of time - especially those that relate to the validation of candidate targets for drugs that might be used to treat human disease.

Jeff Settleman is a Senior Editor at eLife, and is at Calico Life Sciences, South San Francisco, United States

settleman@calicolabs.com

(iD) https://orcid.org/0000-0003-3569-6493

Charles L Sawyers is a Senior Editor at eLife, and is at the Memorial Sloan Kettering Cancer Center, New York, United States

(iD) https://orcid.org/0000-0003-4955-6475

Tony Hunter is a Reviewing Editor at eLife, and is at the Salk Institute for Biological Studies, La Jolla, United States

(iD) https://orcid.org/0000-0002-7691-6993

Competing interests: The authors declare that no competing interests exist.

\section{References}

Alachkar $\mathrm{H}$, Mutonga MB, Metzeler $\mathrm{KH}$, Fulton N, Malnassy G, Herold T, Spiekermann K, Bohlander SK, Hiddemann W, Matsuo Y, Stock W, Nakamura Y. 2014. Preclinical efficacy of maternal embryonic leucinezipper kinase (MELK) inhibition in acute myeloid leukemia. Oncotarget 5:12371-12382. DOI: https:// doi.org/10.18632/oncotarget.2642, PMID: 25365263 Arrowsmith CH, Audia JE, Austin C, Baell J, Bennett J, Blagg J, Bountra C, Brennan PE, Brown PJ, Bunnage ME, Buser-Doepner C, Campbell RM, Carter AJ, Cohen P, Copeland RA, Cravatt B, Dahlin JL, Dhanak D, Edwards AM, Frederiksen M, et al. 2015. The promise and peril of chemical probes. Nature Chemical Biology 11:536-541. DOI: https://doi.org/10 1038/nchembio.1867, PMID: 26196764

Badouel C, Chartrain I, Blot J, Tassan JP. 2010. Maternal embryonic leucine zipper kinase is stabilized in mitosis by phosphorylation and is partially degraded upon mitotic exit. Experimental Cell Research 316: 2166-2173. DOI: https://doi.org/10.1016/j.yexcr.2010. 04.019, PMID: 20420823

Beke L, Kig C, Linders JT, Boens S, Boeckx A, van Heerde E, Parade M, De Bondt A, Van den Wyngaert I, Bashir T, Ogata S, Meerpoel L, Van Eynde A, Johnson CN, Beullens M, Brehmer D, Bollen M. 2015. MELK-T1, a small-molecule inhibitor of protein kinase MELK, decreases DNA-damage tolerance in proliferating cancer cells. Bioscience Reports 35 : e00267. DOl: https://doi.org/10.1042/BSR20150194, PMID: 26431963

Bolomsky A, Heusschen R, Schlangen $K$, Stangelberger K, Muller J, Schreiner W, Zojer N, Caers J, Ludwig H. 2017. Maternal embryonic leucine zipper kinase is a novel target for proliferation associated high-risk myeloma. Haematologica:haematol.2017. 172973. DOI: https://doi.org/10.3324/haematol.2017. 172973, PMID: 29122991

Choi S, Ku JL. 2011. Resistance of colorectal cancer cells to radiation and 5-FU is associated with MELK expression. Biochemical and Biophysical Research
Communications 412:207-213. DOI: https://doi.org/ 10.1016/j.bbrc.2011.07.060, PMID: 21806965

Chung S, Suzuki H, Miyamoto T, Takamatsu N, Tatsuguchi A, Ueda K, Kijima K, Nakamura Y, Matsuo Y. 2012. Development of an orally-administrative MELK-targeting inhibitor that suppresses the growth of various types of human cancer. Oncotarget 3:16291640. DOI: https://doi.org/10.18632/oncotarget.790, PMID: 23283305

Chung S, Kijima K, Kudo A, Fujisawa Y, Harada Y, Taira A, Takamatsu N, Miyamoto T, Matsuo Y, Nakamura Y. 2016. Preclinical evaluation of biomarkers associated with antitumor activity of MELK inhibitor. Oncotarget 7:18171-18182. DOI: https://doi.org/10.18632/ oncotarget.7685, PMID: 26918358

Corsello SM, Bittker JA, Liu Z, Gould J, McCarren P, Hirschman JE, Johnston SE, Vrcic A, Wong B, Khan M, Asiedu J, Narayan R, Mader CC, Subramanian A, Golub TR. 2017. The Drug Repurposing Hub: a nextgeneration drug library and information resource. Nature Medicine 23:405-408. DOI: https://doi.org/10. 1038/nm.4306, PMID: 28388612

Du T, Qu Y, Li J, Li H, Su L, Zhou Q, Yan M, Li C, Zhu Z, Liu B. 2014. Maternal embryonic leucine zipper kinase enhances gastric cancer progression via the FAK/Paxillin pathway. Molecular Cancer 13:100. DOI: https://doi.org/10.1186/1476-4598-13-100, PMID: 24885567

Edupuganti R, Taliaferro JM, Wang Q, Xie X, Cho EJ, Vidhu F, Ren P, Anslyn EV, Bartholomeusz C, Dalby KN. 2017. Discovery of a potent inhibitor of MELK that inhibits expression of the anti-apoptotic protein Mcl-1 and TNBC cell growth. Bioorganic \& Medicinal Chemistry 25:2609-2616. DOI: https://doi.org/10. 1016/j.bmc.2017.03.018, PMID: 28351607

Errington TM, lorns E, Gunn W, Tan FE, Lomax J, Nosek BA. 2014. An open investigation of the reproducibility of cancer biology research. eLife $\mathbf{3}$ : e04333. DOI: https://doi.org/10.7554/eLife.04333, PMID: 25490932

Freedman LP, Gibson MC, Wisman R, Ethier SP, Soule HR, Reid YA, Neve RM. 2015. The culture of cell culture practices and authentication-Results from a 2015 Survey. BioTechniques 59:189-190. DOl: https:// doi.org/10.2144/000114344, PMID: 26458546

Garnett MJ, Edelman EJ, Heidorn SJ, Greenman CD Dastur A, Lau KW, Greninger P, Thompson IR, Luo X, Soares J, Liu Q, lorio F, Surdez D, Chen L, Milano RJ, Bignell GR, Tam AT, Davies H, Stevenson JA, Barthorpe S, et al. 2012. Systematic identification of genomic markers of drug sensitivity in cancer cells. Nature 483:570-575. DOl: https://doi.org/10.1038/ nature11005, PMID: 22460902

Giuliano C, Lin A, Smith J, Palladino A, Sheltzer J. 2018. MELK expression correlates with tumor mitotic activity but is not required for cancer growth. eLife 7: e32838 . DOI: https://doi.org/10.7554/eLife.32838 Gray D, Jubb AM, Hogue D, Dowd P, Kljavin N, Yi S, Bai W, Frantz G, Zhang Z, Koeppen H, de Sauvage FJ, Davis DP. 2005. Maternal embryonic leucine zipper kinase/murine protein serine-threonine kinase 38 is a promising therapeutic target for multiple cancers.

Cancer Research 65:9751-9761. DOI: https://doi.org/ 10.1158/0008-5472.CAN-04-4531, PMID: 16266996

Gu C, Banasavadi-Siddegowda YK, Joshi K, Nakamura Y, Kurt H, Gupta S, Nakano I. 2013. Tumor-specific activation of the C-JUN/MELK pathway regulates 
glioma stem cell growth in a p53-dependent manner. Stem Cells 31:870-881. DOI: https://doi.org/10.1002/ stem.1322, PMID: 23339114

Hebbard LW, Maurer J, Miller A, Lesperance J, Hassell J, Oshima RG, Terskikh AV. 2010. Maternal embryonic leucine zipper kinase is upregulated and required in mammary tumor-initiating cells in vivo. Cancer Research 70:8863-8873. DOl: https://doi.org/10.1158/ 0008-5472.CAN-10-1295, PMID: 20861186 Heinemann B, Nielsen JM, Hudlebusch HR, Lees MJ, Larsen DV, Boesen T, Labelle M, Gerlach LO, Birk P, Helin K. 2014. Inhibition of demethylases by GSK-J1/ J4. Nature 514:E1-E2. DOI: https://doi.org/10.1038/ nature13688, PMID: 25279926

Heyer BS, Warsowe J, Solter D, Knowles BB, Ackerman SL. 1997. New member of the Snf1/AMPK kinase family, Melk, is expressed in the mouse egg and preimplantation embryo. Molecular Reproduction and Development 47:148-156. DOI: https://doi.org/10. 1002/(SICl)1098-2795(199706)47:2<148::AID-MRD4>3. 0.CO;2-M, PMID: 9136115

Hiwatashi K, Ueno S, Sakoda M, lino S, Minami K, Yonemori $\mathrm{K}$, Nishizono Y, Kurahara H, Mataki Y, Maemura K, Shinchi H, Natsugoe S. 2016. Expression of maternal embryonic leucine zipper kinase (MELK) correlates to malignant potentials in hepatocellular carcinoma. Anticancer Research 36:5183-5188. DOI: https://doi.org/10.21873/anticanres.11088, PMID: 27798878

Huang HT, Seo HS, Zhang T, Wang $Y$, Jiang B, Li $Q$, Buckley DL, Nabet B, Roberts JM, Paulk J, Dastjerdi S, Winter GE, McLauchlan H, Moran J, Bradner JE, Eck MJ, Dhe-Paganon S, Zhao JJ, Gray NS. 2017. MELK is not necessary for the proliferation of basal-like breast cancer cells. eLife 6:e26693. DOI: https://doi.org/10. 7554/eLife.26693, PMID: 28926338

Inoue $\mathrm{H}$, Kato T, Olugbile S, Tamura K, Chung S, Miyamoto T, Matsuo Y, Salgia R, Nakamura Y, Park JH. 2016. Effective growth-suppressive activity of maternal embryonic leucine-zipper kinase (MELK) inhibitor against small cell lung cancer. Oncotarget 7:1362113633. DOI: https://doi.org/10.18632/oncotarget. 7297, PMID: 26871945

Janostiak R, Rauniyar N, Lam TT, Ou J, Zhu LJ, Green MR, Wajapeyee N. 2017. MELK promotes melanoma growth by stimulating the NF-KB pathway. Cell Reports 21:2829-2841. DOI: https://doi.org/10.1016/j. celrep.2017.11.033, PMID: 29212029

Ji W, Arnst C, Tipton AR, Bekier ME, Taylor WR, Yen TJ, Liu ST. 2016. OTSSP167 abrogates mitotic checkpoint through inhibiting multiple mitotic kinases. PLoS One 11:e0153518. DOI: https://doi.org/10.1371/ journal.pone.0153518, PMID: 27082996

Kato $T$, Inoue $\mathrm{H}$, Imoto S, Tamada Y, Miyamoto T, Matsuo Y, Nakamura Y, Park JH. 2016. Oncogenic roles of TOPK and MELK, and effective growth suppression by small molecular inhibitors in kidney cancer cells. Oncotarget 7:17652-17664. DOI: https:// doi.org/10.18632/oncotarget.7755, PMID: 26933922 Kohler RS, Kettelhack H, Knipprath-Mészaros AM, Fedier A, Schoetzau A, Jacob F, Heinzelmann-Schwarz V. 2017. MELK expression in ovarian cancer correlates with poor outcome and its inhibition by OTSSP167 abrogates proliferation and viability of ovarian cancer cells. Gynecologic Oncology 145:159-166.

DOI: https://doi.org/10.1016/j.ygyno.2017.02.016, PMID: 28214016
Kruidenier L, Chung CW, Cheng Z, Liddle J, Che K, Joberty G, Bantscheff M, Bountra C, Bridges A, Diallo $H$, Eberhard D, Hutchinson S, Jones E, Katso R, Leveridge M, Mander PK, Mosley J, Ramirez-Molina C, Rowland P, Schofield CJ, et al. 2012. A selective jumonji H3K27 demethylase inhibitor modulates the proinflammatory macrophage response. Nature 488: 404-408. DOI: https://doi.org/10.1038/nature11262, PMID: 22842901

Kruidenier L, Chung CW, Cheng Z, Liddle J, Che K, Joberty G, Bantscheff M, Bountra C, Bridges A, Diallo $H$, Eberhard D, Hutchinson S, Jones E, Katso R, Leveridge M, Mander PK, Mosley J, Ramirez-Molina C, Rowland P, Schofield CJ, et al. 2014. Kruidenier et al. reply. Nature 514:E2. DOI: https://doi.org/10.1038/ nature13689, PMID: 25279927

Kuner R, Fälth M, Pressinotti NC, Brase JC, Puig SB, Metzger J, Gade S, Schäfer G, Bartsch G, Steiner E, Klocker H, Sültmann H. 2013. The maternal embryonic leucine zipper kinase (MELK) is upregulated in highgrade prostate cancer. Journal of Molecular Medicine 91:237-248. DOI: https://doi.org/10.1007/s00109-0120949-1, PMID: 22945237

Li S, Li Z, Guo T, Xing XF, Cheng X, Du H, Wen XZ, Ji JF. 2016. Maternal embryonic leucine zipper kinase serves as a poor prognosis marker and therapeutic target in gastric cancer. Oncotarget 7:6266-6280. DOI: https://doi.org/10.18632/oncotarget.6673, PMID: 26701722

Lin ML, Park JH, Nishidate T, Nakamura Y, Katagiri T. 2007. Involvement of maternal embryonic leucine zipper kinase (MELK) in mammary carcinogenesis through interaction with $\mathrm{Bcl}-\mathrm{G}$, a pro-apoptotic member of the Bcl-2 family. Breast Cancer Research 9: R17. DOI: https://doi.org/10.1186/bcr1650, PMID: 172 80616

Lin A, Giuliano CJ, Sayles NM, Sheltzer JM. 2017. CRISPR/Cas9 mutagenesis invalidates a putative cancer dependency targeted in on-going clinical trials. eLife 6:e24179. DOI: https://doi.org/10.7554/eLife. 24179, PMID: 28337968

Liu H, Sun Q, Sun Y, Zhang J, Yuan H, Pang S, Qi X, Wang H, Zhang M, Zhang H, Yu C, Gu C. 2017. MELK and $\mathrm{EZH} 2$ Cooperate to regulate medulloblastoma cancer stem-like cell proliferation and differentiation. Molecular Cancer Research 15:1275-1286.

DOI: https://doi.org/10.1158/1541-7786.MCR-170105, PMID: 28536141

Marie SK, Okamoto OK, Uno M, Hasegawa AP, ObaShinjo SM, Cohen T, Camargo AA, Kosoy A, Carlotti CG, Toledo S, Moreira-Filho CA, Zago MA, Simpson AJ, Caballero OL. 2008. Maternal embryonic leucine zipper kinase transcript abundance correlates with malignancy grade in human astrocytomas. International Journal of Cancer 122:807-815 DOI: https://doi.org/10.1002/ijc.23189, PMID: 17 960622

Matsuda T, Kato T, Kiyotani K, Tarhan YE, Saloura V, Chung S, Ueda K, Nakamura Y, Park JH. 2017. p53independent p21 induction by MELK inhibition. Oncotarget 8:57938-57947. DOl: https://doi.org/10. 18632/oncotarget.18488, PMID: 28938528

Minata M, Gu C, Joshi K, Nakano-Okuno M, Hong C Nguyen CH, Kornblum HI, Molla A, Nakano I. 2014. Multi-kinase inhibitor $\mathrm{C} 1$ triggers mitotic catastrophe of glioma stem cells mainly through MELK kinase 
inhibition. PLoS One 9:e92546. DOI: https://doi.org/ 10.1371/journal.pone.0092546, PMID: 24739874 Nakano I, Masterman-Smith M, Saigusa K, Paucar AA, Horvath S, Shoemaker L, Watanabe M, Negro A, Bajpai R, Howes A, Lelievre V, Waschek JA, Lazareff JA, Freije WA, Liau LM, Gilbertson RJ, Cloughesy TF, Geschwind DH, Nelson SF, Mischel PS, et al. 2008. Maternal embryonic leucine zipper kinase is a key regulator of the proliferation of malignant brain tumors, including brain tumor stem cells. Journal of Neuroscience Research 86:48-60. DOI: https://doi. org/10.1002/jnr.21471, PMID: 17722061

Nakano I, Kornblum HI. 2009. Methods for analysis of brain tumor stem cell and neural stem cell selfrenewal. Methods in Molecular Biology 568:37-56. DOI: https://doi.org/10.1007/978-1-59745-280-9_4, PMID: 19582420

Pickard MR, Green AR, Ellis IO, Caldas C, Hedge VL, Mourtada-Maarabouni M, Williams GT. 2009. Dysregulated expression of Fau and MELK is associated with poor prognosis in breast cancer. Breast Cancer Research 11:R60. DOI: https://doi.org/ 10.1186/bcr2350, PMID: 19671159

Sharma SV, Haber DA, Settleman J. 2010. Cell linebased platforms to evaluate the therapeutic efficacy of candidate anticancer agents. Nature Reviews Cancer 10:241-253. DOI: https://doi.org/10.1038/nrc2820, PMID: 20300105

Simon M, Mesmar F, Helguero L, Williams C. 2017. Genome-wide effects of MELK-inhibitor in triplenegative breast cancer cells indicate contextdependent response with p53 as a key determinant. PLoS One 12:e0172832. DOI: https://doi.org/10.1371/ journal.pone.0172832, PMID: 28235006

Speers C, Zhao SG, Kothari V, Santola A, Liu M, Wilder-Romans K, Evans J, Batra N, Bartelink H, Hayes DF, Lawrence TS, Brown PH, Pierce LJ, Feng FY. 2016. Maternal embryonic leucine zipper kinase (MELK) as a novel mediator and biomarker of radioresistance in human breast cancer. Clinical Cancer Research 22: 5864-5875. DOl: https://doi.org/10.1158/1078-0432. CCR-15-2711, PMID: 27225691

Stefka AT, Park JH, Matsuo Y, Chung S, Nakamura Y, Jakubowiak AJ, Rosebeck S. 2016. Anti-myeloma activity of MELK inhibitor OTS167: effects on drugresistant myeloma cells and putative myeloma stem cell replenishment of malignant plasma cells. Blood Cancer Journal 6:e460. DOI: https://doi.org/10.1038/ bcj.2016.71, PMID: 27540718

Touré BB, Giraldes J, Smith T, Sprague ER, Wang $Y$, Mathieu S, Chen Z, Mishina Y, Feng Y, Yan-Neale Y, Shakya S, Chen D, Meyer M, Puleo D, Brazell JT, Straub C, Sage D, Wright K, Yuan Y, Chen X, et al. 2016. Toward the validation of maternal embryonic leucine zipper kinase: Discovery, optimization of highly potent and selective inhibitors, and preliminary biology insight. Journal of Medicinal Chemistry 59: 4711-4723. DOI: https://doi.org/10.1021/acs. jmedchem.6b00052, PMID: 27187609

Wang $Y$, Lee $Y M$, Baitsch L, Huang A, Xiang Y, Tong H, Lako A, Von T, Choi C, Lim E, Min J, Li L, Stegmeier F, Schlegel R, Eck MJ, Gray NS, Mitchison TJ, Zhao JJ. 2014. MELK is an oncogenic kinase essential for mitotic progression in basal-like breast cancer cells. eLife 3:e01763. DOI: https://doi.org/10.7554/eLife. 01763, PMID: 24844244

Wang Y, Begley M, Li Q, Huang HT, Lako A, Eck MJ, Gray NS, Mitchison TJ, Cantley LC, Zhao JJ. 2016. Mitotic MELK-elF4B signaling controls protein synthesis and tumor cell survival. PNAS 113:9810 9815. DOI: https://doi.org/10.1073/pnas.1606862113, PMID: 27528663

Xia H, Kong SN, Chen J, Shi M, Sekar K, Seshachalam VP, Rajasekaran M, Goh BKP, Ooi LL, Hui KM. 2016. MELK is an oncogenic kinase essential for early hepatocellular carcinoma recurrence. Cancer Letters 383:85-93. DOI: https://doi.org/10.1016/j.canlet.2016. 09.017, PMID: 27693640 